\title{
Customer Satisfaction Level towards Various Products offered by Signware Technologies, Chennai
}

\author{
Gowtham Ashirvad Kumar, A.Ravikumar
}

\begin{abstract}
This Study on Customer Satisfaction Level towards Various Products offered by Signware advancements, Chennai" goes for the understanding consumer loyalty of the item and Signware Technologies benefits and examine the client inclusion territory of that product. This fulfillment level is a component of contrast between apparent execution and desires. On the off chance that the item's presentation, surpass desire the client exceptionally fulfilled or charmed. On the off chance that the presentation coordinates the desires the client is fulfilled. On the off chance that the items execution fall shorts of desires the client is disappointed
\end{abstract}

Keywords : Signware advancements, Customer Satisfaction Level

\section{INTRODUCTION}

As per Philip Kotler, "fulfillment is an individual's sentiments of weight or disillusionment coming about because of item's apparent exhibition (result) in connection to his or her desires. Consumer loyalty is the degree of an individual's felt state coming about because of looking at an item's apparent presentation (result) in connection to the individual's desires".

This fulfillment level is a component of contrast between apparent execution and desires. In the event that the item's exhibition, surpass desire the client profoundly fulfilled or charmed. In the event that the presentation coordinates the desires the client is fulfilled. In the event that the items execution fall shorts of desires the client is disappointed. [1],[ 3],[5]

\section{REVIEW OF LITERATURE}

Research Question Purpose: Due to natural enactment, financial impacts and expanding worry about the earth among the overall population, the present organizations are ending up progressively dedicated to ecological issues. A few

\section{Revised Manuscript Received on July 22, 2019.}

Gowtham Ashirvad Kumar, Assistant Professor,, Department of MBA,Bharath institute of Higher Education \& Research,Tamilnadu,India, Email: kgowthamaashirwad123@gmail.com

Dr.A.Ravikumar Associate Professor,Department of THM,Bharath institute of Higher Education \& Research,Tamilnadu,India, Email: ravikumar.th@gmail.com

Third Author Name Assistant Professor,Department of MBA,Bharath institute of Higher Education \& Research,Tamilnadu,India, Email: endeavors yet have actualized a green procedure. This proposition targets recognizing issues that decide the long haul productivity of green promoting and how certainty and trust assumes a job so as to increase upper hand through consumer loyalty and client maintenance. The shared factor of both, CRM and green advertising is the making of certainty, trust and incentive for clients. In this way, center is laid around measures that loan believability to organizations' green advertising by meeting specialists and watching their feelings about green promoting and eco-naming..

\section{RESEARCH METHODOLOGY}

Research likewise begins with inquiry or issue .its motivation is to discover answer to address through the candidates of logical strategy it quest for the track with the assistance of the investigation and perception. [2],[4],[6]

Destinations

- To recognize the client feeling towards after deals administration offered to them. [7],[ 9], [11]

- To recognize the upper hand of Signware Technologies' over its rivals. [19],[21],[23]

- To comprehend the requirement for computerization in the customer's area of expertise.

- To survey the viability of framework usage

- To recognize the fulfillment level among the clients towards the costs cited for the product items.

Discoveries

\section{RESULTS}

$1.61 \%$ of individuals acknowledged, $39 \%$ does not acknowledge so these announcement giving data for the majority of the enterprises specialist co-op for any significant businesses. [8],[10], [12]

$2.97 \%$ of individuals all the procedure utilizing just mechanized framework yet just, $3 \%$ of individuals does not utilizing computerized just utilizing manual procedure. [13], [15], [ 17]

3. $50 \%$ of the respondents utilized completely mechanized framework to keep up the information.

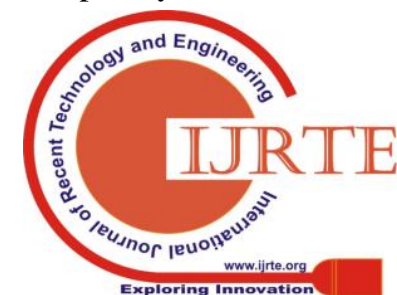




\section{Customer Satisfaction Level towards Various Products offered by Signware Technologies, Chennai}

4. $55 \%$ of the respondents remain unbiased about business forms year on year.

5. $40 \%$ respondents says their efficiency us high. [20],[22], [24]

\section{CONCLUSION}

A features of the investigation on consumer loyalty towards the SIGNWARE TECHNOLOGIES innovation (p) ltd product $76 \%$ individuals like our item for the most part the Signware [25],[27],[29]Technologies item give little scale industries, $80 \%$ people acknowledged our item yet a few people give all the more better deals and administrations Inferred that $37.8 \%$ of individuals firmly concur respondence , 37.4\% organization individuals agree, $20.7 \%$ individuals respondence to fulfill after deals and administrations Find out examining table for the most part $62 \%$ the Signware Technologies item give little scale Industries 17\%Company have an issue of Signware Technologies item. [14],[ 16], [18]

\section{REFERENCES}

1) BharthVajan R., Ramachandran S.,Psychographic dimensions of training,2016,International Journal of Pharmacy and Technology,V-8,I-4,P-23727-23729

2) Balakrishnan P., Bharthvajan R.,A study on human resource planning in hospitals in Chennai City,2014,International Journal of Applied Engineering Research,V-9,I-22,P-7503-7507

3) Priyadarsini P., Bharthvajan R.,Role of emotional intelligence training programme in reducing the stress of the nurses,2014,International Journal of Applied Engineering Research,V-9,I-22,P-7411-7421

4) Kerinab Beenu G., Bharthvajan R.,Empirical analysis on the cosmetic buying behavior of young women in South India,2014,International Journal of Applied Engineering Research,V-9,I-22,P-7361-7366

5) Balakrishnan P., Bharthvajan R.,Whistling in the wind,2014,International Journal of Applied Engineering Research,V-9,I-22,P-7586-7593

6) Krishnan B., Peter M.,Health hazards of Indian Bpo employee-an alarming issue,2014,International Journal of Applied Engineering Research,V-9,I-22,P-7336-7341

7) Kerinab Beenu G.H., Peter M.,Role of insurance in economic development,2014,International Journal of Applied Engineering Research,V-9,I-22,P-7532-7539

8) Balakrishnan P., Peter M., Priyadarsini P.,Efficiency of safety measures for wellbeing of employees in manufacturing industry,2014,International Journal of Applied Engineering Research,V-9,I-22,P-7376-7382

9) Anbarasi M., Praveen Kumar S.,Online sales promotions of herbal products and its effectiveness towards tanisha.com,2019,Indian Journal of Public Health Research and Development,V-10,I-1,P-195-200

10) Anbarasi M., Praveen Kumar S.,Various online marketing and promotions strategies to improve the validation towards the organic products in the pharmaceutical sectors,2019,Indian Journal of Public Health Research and Development, V-10,I-1,P-263-269

11) Loganathan R., Praveen Kumar S.,Grievance handling a key factor for solving issues of employees in an organization,2014,International Journal of Applied Engineering Research,V-9,I-22,P-7483-7491

12) Loganathan R., Praveen Kumar S.,Study on preference of private label brands in super and Hypermarkets,2014,International Journal of Applied Engineering Research,V-9,I-22,P-7327-7335

13) Smitha M., Praveen Kumar S.,Understanding stress and its managementamong the nurses in Chennai city,2014,International Journal of Applied Engineering Research,V-9,I-22,P-7560-7565

14) Kerinab Beenu G.H., Praveen Kumar S.,A study on the investment behavior of Chennai investors in mutual fund schemes,2014,International Journal of Applied Engineering Research,V-9,I-22,P-7520-7525

15) Loganathan R., Praveen Kumar S.,Retention strategies key for organizational productivity,2014,International Journal of Applied Engineering Research,V-9,I-22,P-7443-7447
16) Pavithra J., Ganesan M., Brindha G.,State wise analysis of microfinance sector in India,2016, International Journal of Pharmacy and Technology,V-8,I-4,P-23417-23432

17) Pavithra J., Ganesan M.,A comparative study on microfinance in India and abroad,2016,International Journal of Applied Business and Economic Research,V-14,I-8,P-5471-5476

18) Pavithra J., Ganesan M.,A study on awareness and impact of micro-financial schemes,2016,International Journal of Applied Business and Economic Research,V-14,I-8,P-5449-5460

19) Senthilmurugan P., Pavithra J.,Consumer preference towards organised retailing with reference to Big Bazaar,2014,International Journal of Applied Engineering Research,V-9,I-22,P-7469-7475

20) Senthilmurugan P., Pavithra J.,Implication of social media marketing in growing healthcare industry,2014,International Journal of Applied Engineering Research,V-9,I-22,P-7448-7456

21) Loganathan R., Pavithra J.,Consumer perception towards private label brand over other brands in super markets and hypermarkets,2014,International Journal of Applied Engineering Research,V-9,I-22,P-7355-7360

22) Kerinab Beenu G., Pavithra J.,Tradeâ€"off between liquidity and profitability in logistics industry,2014,International Journal of Applied Engineering Research,V-9,I-22,P-7398-7401

23) Kerinab Beenu G., Pavithra J.,A study on the prospective consumerâ $€^{\mathbf{T M}_{\mathrm{S}}}$ perception towards utility cars in Chennai city,2014,International Journal of Applied Engineering Research,V-9,I-22,P-7526-7531

24) Pavithra J., Dilli Babu P., Ambuli T.V.,A study on budgetary control at Maruti Service Masters, Chennai,2014,International Journal of Applied Business and Economic Research,V-12,I-2,P-151-161

25) Pavithra J., Dilli Babu P., Ambuli T.V.,A study on customer satisfaction of retro Garments Pvt Ltd, Chennai,2014,International Journal of Applied Business and Economic Research,V-12,I-2,P-381-391

26) Kerinab Beenu G.H., Pavithra J., Senthilmurugan P.,A study on the influence of promotional activities for TATA ARIA among consumers in Chennai,2014,International Journal of Applied Engineering Research,V-9,I-22,P-7572-7578

27) Vijayaragavan S.P.,An investigative expert that's general FBG sensors,International Journal of Mechanical Engineering and Technology,V-8,I-8,PP-1500-1505,Y-2017

28) Vijayaragavan S.P.,Equalization routing protocol for Wi-Fi sensor strategy,International Journal of Mechanical Engineering and Technology,V-8,I-8,PP-1662-1666,Y-2017

29) Karthik B., Kiran Kumar T.V.U., Vijayaragavan P., Bharath Kumaran E.,Design of a digital PLL using 0.35 1̂1/4m CMOS technology,Middle East Journal of Scientific Research,V-18,I-12,PP-1803-1806,Y-2013

30) Kanniga E., Selvaramarathnam K., Sundararajan M.,Kandigital bike operating system,Middle - East Journal of Scientific Research, V

31) Jasmin M., Vigneshwaran T., Beulah Hemalatha S.,Design of power aware on chip embedded memory based FSM encoding in FPGA,International Journal of Applied Engineering Research,V-10,I-2,PP-4487-4496,Y-2015

32) Jasmin M.,Optimization techniques for low power VLSI circuits,Middle East Journal of Scientific Research,V-20,I-9,PP-1082-1087,Y-2014

33) Jasmin M., Vigneswaran T.,Fuzzy controller for error control of on - Chip communication,2017 International Conference on Algorithms, Methodology, Models and Applications in Emerging Technologies, ICAMMAET 2017,V-2017-January,I-,PP-1-5,Y-2017

\section{AUTHORS PROFILE}

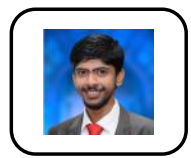

Gowtham Ashirvad Kumar, Assistant Professor, Department of MBA,Bharath institute of Higher Education \& Research,Tamilnadu,India

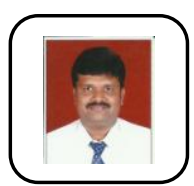

Dr.A.Ravikumar Associate Professor,Department of THM,Bharath institute of Higher Education \& Research,Tamilnadu,India, 